\title{
„Mindenről csak tud, de nem éli át!” - Döntés a heti ingázás mellett iskolai végzettség alapján
}

\author{
KERÜLŐ JUDIT ${ }^{1}$
}

\begin{abstract}
ABSZTRAKT
A tanulmány a belső vándorlók azon csoportját mutatja be, akik optimális esetben is csak hetente tudnak hazautazni családjukhoz. Alapját egy 2019-es interjús vizsgálat adja, amelynek keretében 24 ingázót és otthon maradt családtagját kérdeztek meg arról, miért döntöttek a távolsági munkavégzés mellett. Az interjúk elemzése a megkérdezettek iskolai végzettsége alapján történt, keresve az azonos és eltérő sajátosságokat. A kapott válaszok meggyőzően bizonyítják, minél alacsonyabb iskolai végzettséggel rendelkezik interjúalanyunk, annál inkább jellemzö, hogy csökken a választási lehetösége és nem csak a munkahely esetében nem tud válogatni, de még abban is kiszolgáltatott, hogy hol lakjon, mivel töltse szabadidejét, mikor és mivel utazzon haza.
\end{abstract}

KULCSSZAVAK: belső vándorlás, heti ingázás, szakmai végzettség

\section{ABSTRACT}

„He only knows about everything, but does not experience anything!”deciding on weekly commuting in terms of educational qualifications

This paper presents the group of domestic commuters who can only go home and meet their families - in the best case - once a week. It is based on a survey conducted in 2019 in which 24 commuters together with their family members at home were interviewed about why they had decided on working far away from home. Looking for similar and different characteristic features, we have analyzed the interviews in terms of the respondents' educational qualifications. Our results prove undoubtedly that the lower qualifications the respondents have, the fewer job options they will have; moreover, they are also in vulnerable position concerning getting accommodation, spending free time or finding suitable means of transport to go home.

KEYWORDS: domestic commuter, weekly commuting, professional qualification

\section{Bevezetés}

„A távolsági ingázó hátrányos helyzetben van a helyben dolgozókkal és a bejáró rétegekkel szemben. Státusa ideiglenes lakóhelyén jobbára vendégmunkás-státus" - így

\footnotetext{
${ }^{1}$ Nyíregyházi Egyetem Szociálpedagógia Intézeti Tanszék, kerulo.judit@nye.hu
} 


\section{TEMATIKUS TANULMÁNYOK - „Hetelők” Kelet-Magyarországon}

jellemezte a nyolcvanas évek heti ingázóit Bőhm Antal és Pál László az ingázókról írt könyvükben (Bőhm - Pál 1985: 5).

Ha a távolsági ingázók hátrányos helyzetűek, akkor miért döntenek a hátrányok vállalása mellett? A kérdés egyszerűnek tűnik, de a válasz sokkal összetettebb, soktényezős probléma. Függ az egyén nemétől, iskolai végzettségétől, életkorától, családi állapotától, társadalmi státuszától, lakóhelyétől, a foglalkozáspolitikától és még sorolhatnánk. Mi ebből egyetlen tényezőt emelünk ki, a távolsági ingázó legmagasabb iskolai végzettségét és szakképzettségét. A heti ingázást vállalókat iskolai végzettségük alapján csoportosítjuk, azaz külön elemezzük a diplomás, a középfokú szakmai végzettséggel rendelkezők és a szakképzetlenek motívumait. A továbbiakban a heti ingázókra a kutatás során született „hetelők” kifejezést is használjuk, elkülönítve ezzel a napi és hetente utazókat.

Azt elemezzük, hogy milyen hasonlóságok és eltérések jellemzik iskolai végzettség alapján a legalább egy hétig a családjuktól távol dolgozó megkérdezetteinket. A tanulmány alapját az a 2019 késő nyarán készült 24 interjú adja, amire diplomások, középfokú szakmai végzettséggel rendelkezők és szakma nélküli ingázók, valamint itthon maradt hozzátartozóik válaszoltak. A kutatás az MTA Kiválósági Együttműködési Program Mobilitás Kutatási Centrum keretében zajlott.

\section{A belső vándorlás fogalmi kérdései}

A belső vándorlást Magyarországon 1880-tól lehet nyomon követni, amikortól népszámlálások alkalmával kérdezik a népesség születési helyét és népszámláláskori lakóhelyét. A belső vándorlás megfigyelését segítette elő az is, hogy 1955-ben bevezették a személyi igazolványt. A gazdasági fejlettség és az életminőség különbségei migrációs, vándorlási folyamatokat eredményeznek. A KSH a népszámlások adatfelvételeinél a belső vándorlás esetében állandó jellegű vándorlásnak azt tekinti, ha az egyén állandó lakhelyét változtatja meg. Az e témában lefolytatott kutatások eredményei szerint az állandó jellegű vándorlás jellemzően munkahellyel kapcsolatos okokkal függ össze, de kiválthatják tanulással, egészségi állapottal, családi kapcsolatokkal, házasságkötéssel, válással, az eltartóval, családfővel való költözést generáló tényezők is. Magyarországon az állandó jelleggel költözők elsődleges vándorlási céljai igen erős családorientációt tükröznek, a munkavállalással kapcsolatos okok ehhez képest másodlagosak (Népszámlálás 2011: 8).

Ideiglenes jellegű vándorlásnak azt tekintjük, ha az egyén állandó lakhelye nem változik meg, de munkavállalás vagy tanulás miatt ideiglenesen más településen lakik. Ingavándorlásról akkor beszélünk, ingavándorlóknak azokat nevezzük, akiknek a lakóhelye és munkahelye két különböző településen van, és napi, heti rendszerességgel utaznak a két település között. Tehát azt, hogy valaki heti rendszerességgel utazik lakóhelyére, nevezhetjük ideiglenes jellegű vándorlásnak és ingavándorlás- 


\section{TEMATIKUS TANULMÁNYOK - „Hetelők” Kelet-Magyarországon}

nak is. A hetente utazókat huzamos ingázóként is definiálja a szakirodalom, megkülönböztetve ezzel azokat, akik családjuktól távol élnek, csak ritkább időközönként - hetente - járnak haza, munkás- és egyéb ideiglenes szálláson laknak (Lakatos 2013: 6).

Az ingavándorlást a köznyelvben ingázásként emlegetjük. Az ingázás fontos mutatója egy településnek, mert egyrészt gyakran megelőzi, előkészíti az állandó jellegú vándorlást, a lakóhely változtatását, másrészt jellemzi az adott város, falu foglalkoztatási, tanulási lehetőségeit is. Azt igazolja, hogy van-e a településen az ott élők szakmai végzettségének, elvárásainak megfelelő tanulási, foglalkoztatási alternatíva. Az utazás még akkor is elgondolkodtatja ez egyéneket, ha jó közlekedési infrastruktúrával párosul, azaz megfelelő a tömegközlekedés és a költségek, utazási idő, üzemanyag vagy a bérletek ára többszörösen megtérül. A napi utazás, különösen akkor, ha nem nagy távolságot jelent és nem sok időt vesz igénybe nem jelent lényeges életmódváltást. Pontosan bemérhető az utazással eltöltött idő, ami akár még kellemes is lehet, ha jók a közlekedési, tömegközlekedési adottságok. Más a helyzet a heti ingavándorlással, itt már sokkal több kényelmetlenség társul ehhez az életformához, ilyenek a család hiányából következő hátrányok, de jellemzően a hét közbeni lakhatási lehetőségek is sokkal szerényebbek, kevésé komfortosak, mint az otthoniak. A kérdés, miért vállalkoznak akkor erre az egyének, milyen előnyei lehetnek a kétlaki életnek, mi motiválja az embereket a kényelmetlenségek elviselésére. Írásunkban ezekre a kérdésekre keressük a választ. A heti ingázást vállalókat iskolai végzettségük alapján csoportosítjuk, azaz külön elemezzük a diplomás, a szakmai végzettséggel rendelkezők és a szakképzetlenek motívumait. A továbbiakban a heti ingázókra a kutatás során született „hetelők” kifejezést is használjuk, elkülönítve ezzel a napi és heti utazókat.

\section{Az ingázás alakulása, változásának tendenciái}

A szakirodalom leírja, hogy a vándorlások oka gyakran a foglalkozási lehetőségekkel függ össze. A beköltözés elsősorban nagyvárosok vonzáskörzetében lévő falvaknál tapasztalható. A vándorlás ugyanakkor összefügg az ország gazdaságpolitikájával és településfejlesztési koncepciójával is. Az iparosodással, az urbanizációval és a gazdasági fejlődés sok más egyéb tényezőjével összhangban, egyre intenzívebbé vált a térbeli mobilitásnak mind a két fajtája: a lakóhely-változtatás (vándorlás) és a napi ingázás is (Lakatos 2013: 5).

A 20. században a társadalmi, gazdasági átalakulás egyik jellemzője a lakóhely és a munkahely fokozatos elkülönülése volt. Általánosságban elmondható, hogy a társadalmi, gazdasági fejlődéssel együtt jár a lakóhely és a munkahely térbeli elkülönülése, mivel nem képzelhető el olyan ideális összetételű terület, ahol a különböző foglalkozású, sajátos igényű lakók számára ugyanott, minden vonatkozásban megfe- 


\section{TEMATIKUS TANULMÁNYOK - „Hetelők” Kelet-Magyarországon}

lelő munkahelyek állnak rendelkezésre. De még ha volna is ilyen terület, ezt az ideális állapotot megváltoztatná a fiatalok felnőtté válása, pályaválasztása, az idősebbek nyugdíjba vonulása, a lakásváltoztatás kényszere (Lakatos 2013: 5).

A belső vándorlások volumene az ötvenes évek végétől, a hatvanas évek elejétől kezdve hol erőteljesebben, hol gyengébben, de fokozatosan csökkenő tendenciát mutat. Ebben az időszakban a vándorlás volt az urbanizáció és a társadalmi mobilitás legjelentősebb közvetítő mechanizmusa.

A népszámlálási adatok azt igazolják, hogy az országon belüli vándorlás alapvető iránya a városokból a községekbe, főként a főváros és a nagyvárosok közeli agglomerációs körzetben lévő községekbe történő migráció, tehát többen vándorolnak községekbe, mint ahányan onnan elvándorolnak. A régión belüli mozgások esetén viszont a hátrányos helyzetű kistelepülésekről történő elvándorlás a jellemző, elsősorban a magasabban kvalifikált népesség körében. A szegényebb és alacsonyabban képzett lakosság előtt az elköltözés lehetősége többnyire bezárul. A kedvezőtlen migrációs folyamatok a lemaradó régiók esetében a hátrányok további halmozódásához vezetnek (Népszámlálás 2011: 8).

A népszámlálások az ideiglenes jellegű vándorlókról vagy távolsági ingázókról azt mutatják, hogy elsősorban olyan alacsony kvalifikált, szakképzetlen munkások tartoznak abba a csoportba, akik helybeli munkalehetőség hiányában lakóhelyüktől távol dolgoznak, és emiatt nem tudnak naponta hazajárni. A szocialista rendszer foglalkoztatáspolitikája elsősorban a fővárosban és a megyeszékhelyeken munkásszállások építésével és működtetésével tartotta fenn a távolsági ingázást (Népszámlálás 2011: 8).

Az ingázás vagy ingavándorlás az ötvenes évek iparosítása következtében ugrásszerűen megnőtt. 1960-ban a több mint 600 ezer ingázó az aktív keresők 15 százalékát jelentette. A hatvanas években az ingázók száma a nők munkába állásával párhuzamosan folyamatosan nőtt. Az ötvenes-hatvanas években az ingázás növekedésében fontos szerep jutott a foglalkoztatáspolitika által befolyásolt tényezőknek, a mezőgazdaság erőszakos kollektivizálásának, az iparban dolgozók magasabb bérezésének, az akkor még alig létező állami bérlakások alacsony számának és az olcsó vasúti közlekedésnek (Tóth 2008: 8).

Az 1960. évi népszámlálás az ingázók társadalmi összetételére is szolgál adatokkal: körükben a fiatal, fizikai munkát végző férfiak voltak többségben, akik akkor főként az iparban, az építőiparban és a közlekedésben dolgoztak (Népszámlálás 1960: 9, 1963)

Egy 1966-ban készült felvétel szerint az ingázások több mint fele megyéken belül történt, közel egyharmaduk Budapestre irányult és csak 13\% volt a megyék közötti ingázás részesedése. A megyéken belüli ingázások is főként az iparilag fejlettebb és nagyobb lakosságszámú megyékben történtek (Losonczi 1968: 746). Ekkor közel 900 ezer volt az ingázók száma, kb. 20\%-uk nem naponta, hanem hetente, kéthetente utazott haza (Kovács et al. 2015: 237). 


\section{TEMATIKUS TANULMÁNYOK - „Hetelők” Kelet-Magyarországon}

1970-ben 320 ezer fő távolsági ingázót mutatott a népszámlálás, akik a „tartós ideiglenesség" állapotára rendezkedtek be, ágybérlők, albérlők vagy munkásszállások lakói voltak. Munkásszállón 1955-ben 110 ezren, 1961-ben 225 ezren, az 1970es évek végén 150 ezren és a nyolcvanas évek közepén 120 ezren főként az ipari és építőipari segéd és betanított munkások átlagosan 5-8 évig éltek (Böhm 1997: 38, Valuch 2001:70).

Az ingázók száma és aránya 1980-ig folyamatosan növekedett, amikor több mint 1,2 millió munkavállaló, a foglalkoztatottak közel egynegyede utazott lakóhelye és a munkahelye között. Ez volt a csúcspontja a szocialista típusú, főként az iparba irányuló, uralkodóan falu-város relációkban lebonyolódó és nemegyszer nagy távolságokat áthidaló ingázásnak hazánkban (lásd „fekete vonatok”) (Dövényi et al. 2011: 90, Tóth 2008).

A rendszerváltás után az ingázók számának erőteljes csökkenése volt megfigyelhető, amelyet a kutatók a gazdasági szerkezetváltás és a növekvő munkanélküliség következményeként értelmeznek. Kovács és munkatársai vizsgálták az ingázás jellemzőinek változását a rendszerváltás utáni Magyarországon (Kovács et al. 2015). Azt tapasztalták, hogy az új helyzet nyomán az ingázás intenzitása, jellege és földrajzi mintázata számottevően átalakult, az államszocialista ('konzervált fordi típusú') ingázást fokozatosan egy 'posztfordi' térbeli struktúra váltotta fel (Kovács et al. 2015: 233). A növekvő és 1990 után térben egyre összetettebb ingázás mögött számos okot találtak. Egyrészt a tervutasításos gazdasági rend összeomlása rengeteg (ipari) nagyfoglalkoztató megszűnését eredményezte. A munkahelyek korábbi térbeli egyensúlya felbomlott, a nagy nehézipari körzetek kiürültek, az új, a globális gazdaság szereplői által létrehozott munkahelyek pedig egyre nagyobb arányban a főváros térségébe, illetve más dinamikus várostérségekbe (például Győr, Székesfehérvár) települtek. Ennek nyomán mind több munkavállaló kényszerült arra, hogy „utána menjen” munkahelyének, akár állandó vándorlás, akár kisebb léptékű periodikus mozgás formájában (Dövényi 2011).

Átalakult a munkavégzés jellege is, a három műszakban végzett, rutin jellegű munka szerepe leértékelődött, nőtt a részfoglalkoztatás és a távmunka súlya, és mindez lehetőséget teremtett a térben és időben rugalmasabb munkavégzésre, benne az ingázás új formáinak elterjedésére.

Ám ha az aktív keresők körében vizsgáljuk az ingázók arányát, további növekedés tapasztalható. 1980 óta változatlanul minden 100 aktív keresőből 25 fő napi rendszerességgel ingázik. Az ingázók 80 százaléka 25 kilométernél kevesebbet, átlagban napi 30 percet utazik. Jelentős részük éppen a szuburbanizáció miatt nagyvárosok közelében él és onnan vállalkozik napi utazásra. A főváros és a megyeszékhelyek környékéről ingázók között ugyanúgy megtaláljuk a magas iskolai végzettségűeket, mint a szakmunkásokat, segéd és betanított munkát végzőket (Népszámlálás 2011: 8). 


\section{TEMATIKUS TANULMÁNYOK - „Hetelők” Kelet-Magyarországon}

A rendszerváltás után a legnagyobb mértékben a távolsági ingázás feltételei alakultak át. Nagyságrendje radikálisan csökkent, míg 1980-ban 270 ezer ember vállalta az ideiglenes vándorlást, addig 1990-re számuk a felére, a kilencvenes évek végére, egynegyedére csökkent. A távolsági ingázók több mint fele Budapesten dolgozik (Népszámlálás 2011: 8).

Az ingázással kapcsolatos nemzetközi szakirodalom fóként három szempontot vizsgál. Az ingázási (utazási) időt (Gordon et al. 1989), az ingázás távolságát (Banister 2011) és az ingázók nemét (Clark et al. 2003).

\section{A kutatásról}

2019 augusztusában és szeptemberében félig strukturált interjúk készültek azokban a megyékben, ahol a szakirodalom szerint kiemelkedően magas az ingázók száma és ezek az arányok az elmúlt évtizedekben radikálisan nem változtak. A mintába került családok Hajdú-Bihar, Szabolcs-Szatmár-Bereg, Borsod-Abaúj-Zemplén és Jász-Nagykun-Szolnok megye területén élnek. Összesen 9 településen történt interjúfelvétel. A települések jellemzően kistelepülések, de városi, nagyvárosi agglomerációban élő megkérdezettek is bekerültek a mintába. Az interjúerek kapcsolataikra, ismeretségükre támaszkodva keresték meg az ingázókat és családtagjaikat. Törekedtek arra, hogy mindkét partnerrel, a hetelővel és annak itthon maradt családtagjával is készüljenek interjúk, de ezt éppen a távollévők miatt nem mindig sikerült megvalósítani. Az otthon tartózkodás rövid idejében nehéz volt olyan időpontot találni, amikor egy interjú elkészíthető lett volna, így előfordult, hogy csak az otthon maradt felet sikerült megkérdezni. Összesen 24 interjú készült el, ebből 11 hetelő és 13 otthon maradó interjúalanyunk véleménye ismerhető meg. Az ingázók közül 9 férfi és 2 nő válaszolt a kérdésekre, az otthoniak valamennyien nők voltak. Minden interjút hangfelvételen rögzítettek a hallgatók. A megkérdezettek iskolai végzettségét az 1. számú táblázat mutatja. A legfiatalabb megkérdezett 18 éves, a legidősebb pedig 54 éves volt. Az interjúkat név nélkül vették fel a vizsgálatban résztvevő diákok.

A kutatás az MTA Kiválósági Együttmúködési Program Mobilitás Kutatási Centrum keretében zajlott. 
www. metszetek.unideb.hu

\section{TEMATIKUS TANULMÁNYOK - „Hetelők” Kelet-Magyarországon}

1. táblázat. A megkérdezettek jellemzői

\begin{tabular}{|c|c|c|c|c|c|}
\hline Sorszám & Neme & Életkora & Iskolai végzettsége & Foglalkozása & $\begin{array}{c}\text { Otthon } \\
\text { maradó/hetelő }\end{array}$ \\
\hline 1. & Nő & 34 & felsőfok & tanító & Otthon marad \\
\hline 2. & Férfi & 44 & Középfok, technikus & kamionsofőr & Hetelő \\
\hline 3. & Nő & 46 & Felsőfok & Középiskolai tanár & Otthon marad \\
\hline 4. & Nő & 27 & Felsőfok & Állami tisztviselő & Otthon marad \\
\hline 5. & Nő & 46 & Felsőfok & Tanár & Otthon marad \\
\hline 6. & Nő & 45 & Felsőfok & Eü. asszisztens & Otthon marad \\
\hline 7. & Nő & 31 & $\begin{array}{l}\text { Érettségi, szakmai } \\
\text { végzettség }\end{array}$ & Szociális gondozó & Otthon marad \\
\hline 8. & Nő & 50 & Érettségi & Óvodapedagógus & Otthon marad \\
\hline 9. & Férfi & 54 & $\begin{array}{l}\text { Érettségi, szakmai } \\
\text { végzettség }\end{array}$ & Csőszerelő & Hetelő \\
\hline 10. & Nő & 50 & $\begin{array}{l}\text { Érettségi, szakmai } \\
\text { végzettség }\end{array}$ & $\begin{array}{l}\text { Mérlegképes } \\
\text { könyvelő }\end{array}$ & Otthon marad \\
\hline 11. & Nő & 44 & $\begin{array}{l}\text { Érettségi, szakmai } \\
\text { végzettség }\end{array}$ & Bolti eladó & Otthon marad \\
\hline 12. & Nő & 18 & $\begin{array}{l}\text { Érettségi, szakmai } \\
\text { végzettség }\end{array}$ & Pincér & Otthon marad \\
\hline 13. & Nő & 29 & Szakiskola & Bolti eladó & Otthon marad \\
\hline 14. & Férfi & 37 & Szakiskola & Soför & Hetelő \\
\hline 15. & Férfi & 25 & $\begin{array}{l}\text { 10. osztály, szakmai } \\
\text { végzettség }\end{array}$ & Burkoló & Hetelő \\
\hline 16. & Férfi & 40 & $\begin{array}{l}\text { 8. osztály, szakmai } \\
\text { végzettség }\end{array}$ & $\begin{array}{l}\text { Építőipari } \\
\text { szakmunkás }\end{array}$ & Hetelő \\
\hline 17. & Férfi & 40 & $\begin{array}{l}\text { 8. osztály, szakmai } \\
\text { végzettség }\end{array}$ & Asztalos & Hetelő \\
\hline 18. & Férfi & 38 & $\begin{array}{l}\text { 8. osztály, szakmai } \\
\text { végzettség }\end{array}$ & Kőműves & Hetelő \\
\hline 19. & Férfi & 21 & $\begin{array}{l}\text { 8. osztály, szakmai } \\
\text { végzettség }\end{array}$ & Villanyszerelő & Hetelő \\
\hline 20. & Férfi & 45 & 8. osztály & Segédmunkás & Hetelő \\
\hline 21. & Nő & 24 & 8. osztály & Segédmunkás & Hetelő \\
\hline 22. & Nő & 38 & 8. osztály & Háztartásbeli & Otthon marad \\
\hline 23. & Nő & 33 & 8 osztály & Közmunkás & Otthon marad \\
\hline 24. & Nő & 41 & 8 osztály & Betanított munkás & Hetelő \\
\hline
\end{tabular}

Forrás: Saját szerkesztés 


\section{TEMATIKUS TANULMÁNYOK - „Hetelők” Kelet-Magyarországon}

\section{A diploma sem ment meg az ingázástól? - Diplomások az ingázásról}

Az ingázással kapcsolatos KSH felmérések, időmérleg vizsgálatok adatai szerint a napi vagy heti munkahelyre utazók főként férfiak, alacsonyabb iskolai végzettségüek, közöttük jóval kevesebben vannak a nők és a magasabb iskolai végzettségűek. A diplomás napi ingázók jellemzően a főváros vagy a nagyvárosok agglomerációjában élnek, jó közlekedési infrastruktúra áll rendelkezésükre. A heti rendszerességgel utazók között viszont már alig találunk főiskolát, egyetemet végzett munkavállalót. Akik közülük mégis távolsági ingázók, azok többnyire olyan speciális végzettséggel rendelkeznek, amivel lakóhelyükön nem, vagy csak alacsonyabb státuszban, alacsonyabb bérért tudnának elhelyezkedni (Lakatos 2013: 8). Ingázásuk oka röviden összefoglalva a karrier és a pénz.

A vizsgálatban résztvevők között egyetlen olyan hetelő volt, aki diplomával rendelkezik. Nagyvárosi agglomerációban él, évtizedeken keresztül napi szinten ingázott a néhány kilométerre lévő megyeszékhelyre. Olyan speciális végzettséggel rendelkezik, amivel az adott településen csak egyetlen olyan munkahelyen tudna elhelyezkedni, ahol szakmai végzettségének és érdeklődésének megfelelően munkát tud vállalni. Több mint 10 évet dolgozott itt, első számú vezető volt, majd egy munkahelyi átszervezés miatt egyik kollégája, korábbi beosztottja került a cég élére. Az új helyzetben nem találta meg a helyét és mivel helyben nincs képzettségének és tapasztalatának megfelelő munka, a hetelés mellett döntött. Interjú a feleségével készült, aki szintén diplomás.

A felesége így indokolta a hetelés melletti döntést:

„Hát ez egy érdekes dolog, mert Ő itt vezető beosztásban volt. Amikor valaki vezető beosztásban van és onnan, hogy is mondjam, eltávolítják, akkor már nem biztos, hogy olyan jó alkalmazottként, ügyintézóként is ott dolgozni. Nyilván fizetésben sem mindegy, de a körülmények sem úgy alakultak, nem tudott Ő már abban a környezetben beosztottként dolgozni és Budapesten megkapta azokat a lehetôségeket, amiket korábban itt is megkapott". (3. interjúalany)

A budapesti munkavállalást megkönnyítették azok a szakmai kapcsolatok, amelyeket korábbi években alakított ki. Emiatt nem jelentett gondot megfelelő munkát találni és beilleszkedni az új helyre, új közösségbe.

A felesége szerint döntésük hosszú távú, nem terveznek sem elköltözést, sem pedig helybeni munkavállalást.

„Majd meglátjuk, hogy lesz később, ehhez nagy változásnak kell történnie, hogy ő itt labdába tudjon rúgni. Mert most azt, amit ő itt felépített, feladni, azt meg és sem várom el tőle, hogy feladja, hogy lerombolja az egész eddigi munkáját." (3. interjúalany) 
Nyilván a magasabb iskolai végzettség, speciális, keresett szakképzettség olyan fizetést, jövedelmet is jelent, ami lehetővé teszi a hetelő számára, hogy a munkahelyen lévő településen is komfortosabb körülmények közöttéljen és rugalmas munkaidőben dolgozva meg tudja valósítani azt, hogy csak 4 napot legyen távol a családtól. A távolsági munkavégzés melletti döntését segíti a jó közlekedés, hiszen 2 óra alatt még vonattal is haza tud érni és a megfelelő jövedelem. Nem az anyagiak határozzák meg az utazás módjának kiválasztását, hanem az aktuális helyzet, a programok, az itthoni elfoglaltságok. A fontos családi eseményeket, döntéseket pedig az otthon töltött 3 napra próbálják szervezni.

„Hát péntekenként és hétvégeken, amikor itthon van, akkor húzgálja a gyerekeket össze-vissza, még túlzásba is viszi." (3. interjúalany)

\section{Hetelők középfokú végzettséggel}

A kutatásban megkérdezett hetelők jellemzően középfokú végzettséggel és szakmával rendelkeznek. Többen nem korábbi szakmájukban dolgoznak, mert vagy nem találtak helyben megfelelő munkát vagy más területen jobb lehetőségeik adódtak.

A rendszerváltást követő évtizedek gazdasági történései nemcsak a foglalkoztatottságban idéztek elő fordulatot, hanem a munkahelyek térbeli struktúráját is áthelyezték. A nagy létszámú alkalmazottat foglalkoztató ipari üzemek és mezőgazdasági termelőszövetkezetek megszűnésével az ország korábban is hátrányos helyzetû térségeiben még erőteljesebben beszűkültek a helyben való munkalehetőségek, a munkaerő-kínálat jellemzően nagyobb volt, mint a kereslet. Az elhelyezkedést nehezítette a strukturális munkanélküliség, ami egyben azt is jelentette, hogy vagy újabb, keresett szakma elsajátítására vállalkozik az egyén vagy más térségben kell elhelyezkednie. Az állandó vándorlást akadályozza a nagyon alacsony lakásmobilitás, ami a régiók közötti eltérő ingatlanár különbséggel függ össze.

„Hát a mi házunk adó és hitelmentesen épült fel, nem fogom elkótyavetyélni azzal, hogy elköltözzek innen. Egy élet megy rá egy családi házra és máshol pedig nem kapnék érte semmit, így hát maradnunk kell itt." (9. interjúalany)

Az Európai Unióhoz való csatlakozás megnyitotta a külföldi munkavállalási lehetőségeket is, főként a szakmával rendelkezők számára.

„2008-ig, ameddig a válság be nem jött, addig én jól kerestem. De ugye a munka az mindig kevesebb és kevesebb lett, egyszer csak elfogyott, ez már 2009 februárjában volt, itthon voltam 3 hónapig, próbálgattam, nézelődtem, sehol sem volt igazán nagy lehetöség. Akkor döntöttem úgy, hogy felhívom az isme- 


\section{TEMATIKUS TANULMÁNYOK - „Hetelők” Kelet-Magyarországon}

rôsömet, aki kint dolgozik pár éve Ausztriába és végül így kerültem ki.” (9. interjúalany)

A megkérdezettek egy része olyan szakmai végzettséggel rendelkezik, amivel valószínűleg itthon is, talán még a lakóhelyén is találna munkát.

„Csak az anyagiak miatt választottuk ezt a munkaformát. Mert soförként bármikor, bárhova el tudna itthon is helyezkedni, ez nem kérdés. Nyilván egy napon nem lehet említeni egy DKV-s buszsoföri fizetéssel, annak négy, ötszörösét keresi meg így." (1. interjúalany)

„Amikor a válság bejött, akkor volt az a cég, akinél dolgoztam. Ugye azt mondták, hogy ôk el fognak járni Pestre dolgozni, de csak úgy, hogy hétfón mennek és pénteken jönnek haza. Én azt mondtam nekik, hogy ide figyelj, már a fönöknek, ide figyelj, ha én itthonról elmegyek, akkor én nem Pestig megyek, hanem tovább. Nos, nehogy azt hidd, hogy el fogok menni, most 150 ezer forintért Pestre, amiből még elég sokat el is költ az ember, akkor már megyek Ausztriába vagy Németországba, akkor már keressek annyit, amennyiért megéri a távollét, nincs igazam?" (9. interjúalany)

A külföldre irányuló heti ingázásnak elsődlegesen a nagyobb jövedelem a motivációja és azok a plusz juttatások, amelyek a kinti munkavállaláshoz kapcsolódnak.

„Hát fontosak az úgymond juttatások is. Tehát egészségügyi ellátás, az sokkal jobb, mint itthon és a cég is korrektebb, mint mondjuk egy magyarországi vállalkozó. Volt már kint kórházban, kint mütötték a térdét, hát össze nem lehet hasonlítani egy itthoni ellátással." (11. interjúalany)

A nagyobb jövedelem pedig lehetővé teszi, hogy a család az adott településen átlagos életet tudjon élni, legyen saját tulajdonú ingatlanja, az otthon maradt családtagnak, többnyire feleségnek önálló autója és esetleg nyaralni is el tudjanak menni.

Megkérdezetteink a kinti elhelyezkedésnél nagyon fontosnak tartják a szakmai végzettséget, ezen belül is azokat, amelyek az adott országban keresettek.

„Csak akkor adtak állandó munkavállalási engedélyt, ha olyan szakmában akartál kimenni dolgozni, ami mondjuk Ausztriában hiányszakma. Kellett hozzá egy hegesztői minősítés, azt megszereztem. Tehát csak így lehet, tehát nem úgy, hogy kocsiba ülök és megyek és dolgozok. Lehet persze, meg sokan is dolgoztak szakma nélkül, de csakfeketén." (9. interjúalany) 


\section{TEMATIKUS TANULMÁNYOK - „Hetelők” Kelet-Magyarországon}

A hét közben külföldön dolgozó középfokú szakmai végzettséggel rendelkező munkavállalók rendszerint szerény körülmények között panzióban vagy munkásszálláson laknak. Fontos, hogy az általuk megkeresett jövedelemből minél kevesebbet költsenek, ezért elfogadják a szűkös szobákat, olcsó szálláslehetőségeket is.

„Hát van egy szállás, ahol már jó pár éve ott szoktam megszállni, egy kis szoba, egy ilyen egyszemélyes kis szoba, van benne ágy, hütö, egy kisszekrény, meg TV, meg külön egy pici fürdőszoba. Este 6 óra után felmegyek, valamit eszegetek és nézem a laptopomon a sorozatokat." (9. interjúalany)

„Hát elmennek korán dolgozni, ötre járnak és így már 2 óra magasságában végeznek a munkával, utána többnyire a szállón vannak, olyan egyszerú a szállásuk." (11. interjúalany)

Bár az interjúk során konkrétan nem került szóba az adott ország nyelvének ismerete, de arra történnek utalások, hogy rendszerint a munkaidő végén azonnal hazamennek, többnyire ekkor beszélnek az itthon maradottakkal telefonon, skype-on. Jellemzően a saját laptopjukon sorozatot néznek, tehát nem igazán használják a nyelvet, legfeljebb a munkahelyükön. A nyelvi ismeretek nem megfelelő szintje akadályozhatja a munkahelyi hierarchiában való előrelépést, középvezetővé válást, hiszen akinek már beosztottja van, az kénytelen idegen nyelven kommunikálni kollégáival. A kinti szúkös, többnyire Magyarországról érkezettekre korlátozódó kapcsolatok azt mutatják, hogy a külföldi munkavállalást megkérdezetteink vagy átmenetinek tekintik, vagy továbbra is a lakóhely és a munkahely térbeli szétválasztásával képzelik el. Nem tartják reálisnak az adott országban való átköltözést.

A magyarországi középfokú végzettséggel rendelkező heti ingázók motivációja között jellemzően három tényező szerepel. A végzettségnek megfelelő munkalehetőség, a helyben lévő béreknél magasabb fizetés, szakmai tapasztalatok, referenciák megszerzése.

„Kényszerhelyzet miatt kellett elvállalnia. Építóiparban dolgozik, ilyen végzettsége van és az a cég, ahol jelenleg is dolgozik, az ország másik végén vállalt munkát. Nem volt más választása, mennie kellett, mert azért ott jobban fizették, több mindent meg tudtunk engedni magunknak, ennyi." (7. interjúalany)

„Igazán anyagi vonzata van a dolognak, tehát, ha helyben lenne egy ehhez hasonló munkabér és mondjuk napi szinten hazajárna, biztos vagyok benne, hogy azt választaná. De én úgy gondolom, hogy anyagi vonzata van a dolognak." (10. interjúalany) 


\section{TEMATIKUS TANULMÁNYOK - „Hetelők” Kelet-Magyarországon}

„Hát fizetésben nem szabolcsi fizetést kap. Illetve olyan cégnél van, ahol neki ez referenciának is megfelel, mert olyan referencia munkái vannak, amelyek által tapasztalatot szerez... Tényleg annyi mindent csinálnak, hogy tényleg tudásilag nagyon sokat nyert már most is." (4. interjúalany)

Mivel az anyagiak, a magasabb munkabér fontos tényező, ezért a középfokú végzettséggel rendelkező belföldre ingázó megkérdezetteink is hasonlóan a külföldön dolgozókhoz arra törekszenek, hogy a hét közbeni létfenntartási költségeiket minimalizálják. A szállást többnyire a munkáltató fizeti, az étkezést is igyekeznek olcsón, maguk megoldani.

„Egy panzióban vannak elszállásolva, egyébként, amit a cég fizet számukra. Tehát nem munkásszálló, hanem rendes panzió. Tömegközlekedéssel eljut a helyszínre, ahol ugye dolgoznak. Ott dolgozik általában 10 óra hosszát, neki ennyi a munkaidő, majd visszautazik a szállásra, esetleg elmegy a boltba vagy föz magának, vacsorázik, játszik a számítógépén és alvás, szerényen él." (4. interjúalany)

Ami az interjúkból kiderül, hogy a magyarországi heti rendszerességgel ingázók gyakorta nem napi 8 órát dolgoznak. Ezt a megkérdezettek nem bánják, egyrészt a magasabb kereset miatt, másrészt, mert így jobban telik az idő.

\section{Heti ingázás szakmai végzettség nélkül}

Gmelch szerint egy falusinak élete során a munkalehetőségek és a migráció szempontjából az alábbi döntési alternatívákkal kell szembenéznie: 1. Otthon marad, és a mezőgazdaságban dolgozik. 2. A közeli városba megy dolgozni és naponta ingázik. 3. A nagyvárosban vállal munkát, de hétvégenként hazatér. 4. Családjával együtt költözik a nagyvárosba, és felszámolja korábbi háztartását. 5. Kedvező munkalehetőség reményében külföldre költözik (Gmelch1996: 190).

2010 után a szakmai végzettség nélküliek számára a településhierarchia alacsonyabb szintjein egyre inkább csak az állam által fenntartott munkahelyek, ezen belül a közszolgáltatások, közmunkaprogramok váltak elérhetővé. A piaci szereplők - azon belül is a magas hozzáadott értéket előállítani képes cégek - amiatt is elkerülik a kisebb, jellemzően ötezer fő alatti településeket, mert helyben nincs elegendő számban szakképzett munkaerő (Kovács et al. 2015: 251).

A szakmai végzettség híján lévők nem tudják szaktudásukat eladni, legfeljebb csak fizikai erejüket lesznek képesek kamatoztatni. Mivel a helyi munkalehetőségek a vizsgált megyékben legfeljebb a közmunkaprogramokra korlátozódnak, így az ingázás esetükben nem választás, hanem kényszer. Sem otthon, sem a közeli városban nincs esélyük munkát kapni, így marad a távoli munkavégzés. 


\section{TEMATIKUS TANULMÁNYOK - „Hetelők” Kelet-Magyarországon}

„Itt nincsen megélhetés, annyi. Itt nincs munkahely, ezért el kell innen menni dolgozni. Itt semennyire nincs munka. Ha lenne is, nagyon keveset fizetnek, ez a közmunka." (15. interjúalany)

Hasonlóan látja a helyzetét egy másik megkérdezettünk is.

„Tehát innen csak ki kell emelkedni, mert aki itt legyökerezik, annak vége. Aki számít, az mind abba az irányba gondolkodik, hogy el kell járni Pestre dolgozni, ha meg akarnak élni, ki akarnak mászni a sárból, nem itt akarnak toporzékolni, meg lesüllyedni a sárba, ki akarnak emelkedni. Azt akarom, hogy a családtagjaim is ezt csinálják.” (16. interjúalany)

Többnyire nehéz fizikai munkát végeznek, gyakorta napi 9-10 órában, de ha a munka úgy kívánja, akkor a hétvégén is dolgoznak, ilyenkor elmarad, ritkul a hazautazás. Munkaidejükön, beosztásukon többnyire nincs lehetőségük változtatni, legfeljebb, ha valami fontos családi esemény miatt szeretnének haza utazni, akkor arra kapnak lehetőséget.

„Nem, nem jövök minden héten haza, ahogy a munka megengedi, most úgy van, hogy 3 hónap után jöttem, meg hosszabb idő után.” (15. interjúalany)

A gyakori hazautazás ellen szóló további érv a magas útiköltség. 3-400 kilométernyi utazás, vonattal több, mint 15 ezer forintba kerül és a cégek ritkán fizetik az utazással kapcsolatos költségeket. Így még akkor is átgondolandó a hazaút, ha egyébként a munka ezt lehetővé tenné.

Nincsenek abban a helyzetben, hogy a távoli, főként fővárosi, dunántúli munkahelyek között válogassanak, odamennek dolgozni, ahol van ismerősük vagy szakmai végzettség nélkül is felveszik őket. Munkabérek is csak az itthoni, közmunkás bérekhez képest magasabb, jó esetben bejelentett, nem feketemunkát végeznek.

„Az szomorú, hogy 400 kilométerre kell innen lenni, távol a családtól, hogy meg tudjunk egy kicsit élni, egy kicsit jobban élni a lehetőségekkel." (18. interjúalany)

„Hát amióta eljárok dolgozni, annyira változott, hogy könnyebben ki tudjukfizetni a számláinkat, a megélhetés jobb, mert addig nagyon kevés volt, nagyon be kellett osztani. Most is beosztjuk, hogy télére is legyen, próbálunk egy keveset félrerakni, mert ha nincs munka, akkor legyen, amiból megéljünk." (16. interjúalany) 


\section{TEMATIKUS TANULMÁNYOK - „Hetelők” Kelet-Magyarországon}

„Most Fehérváron dolgozunk 1600 forintos órabérrel, napi jelentéssel. Abból mi fizessük magunknak a szállást, pénzt nekünk kell vinni, hogy hát ellássuk magunkat. Nem sok, de ez is több mint a semmi." (16. interjúalany)

Az is gyakori, hogy saját településükről visznek magukkal ismerősöket, rokonokat, családtagokat, akikkel együtt laknak, együtt utaznak, esténként együtt vannak. Úgy látják, hogy személyes sorsukkal példát is mutatnak, aminek a hatására mások is felvállalják az ingázást.

„Amikor én elkerültem Fehérvárra, akkor én innen Szatmárcsekéről még 13 embert vittem magammal. Volt egy hét személyes platós busz, amivel hordtuk az embereket. Tehát egy szálláson voltunk, mi csak helyiek.” (16. interjúalany)

„Amikor mi hazajövünk, akkor hallották, hogy jó a munka, úgyhogy úgy mennek dolgozni, ha lássák, hogy kifizetik öket, jó hírt viszünk a cégröl, elmernek menni, mi is, meg van itt pár család, mi vagyunk a példa." (16. interjúalany)

Azt is látják, ahhoz, hogy hosszútávon munkahelyük legyen, tanulni kell, tanulni kellene. Egyelőre csak a különböző munkafajták betanulásában látják a jövőt.

„Én Pesten építôiparban dolgozom. Hát így az, hogy mindent csinálni kell, meg kell tanulni mindent, azért, hogy egy jó munkahelyen, egy cégnél beváljál, hogy hosszú távon munkalehetőséged legyen, a vasszerelést, szigetelést, meg minden mást." (17. interjúalany)

A szállásuk többnyire olcsó, komfort nélküli munkásszállás vagy albérlet. Ha azzal nincsenek megelégedve, akkor kereshetnek másikat, de abban az esetben ők fizetik annak költségeit. Többnyire az egy faluból érkezők együtt laknak.

„Hát a szállás nagyon nem volt jó. Csak ígérgette a fönök, hogy lesz jobb szállás, fürdési lehetőség sem volt, csak hideg víz.” (16. interjúalany)

„Persze van a céges albérlet, de az nagyon rossz. De most, hogy én külön menjek, mert itt vannak a családtagok is, akkor én fizetem az albérletet.” (17. interjúalany)

Nem gondolkodnak, nem gondolkodhatnak abban, hogy az ingavándorlást állandó vándorlásra módosítsák, hiszen az otthoni ingatlan árából szinte semmit sem tudnának a főváros környékén vásárolni. Válaszaikban megjelenik a kényszerből való immobilitás, mely szerint nincs reális alternatívája annak, hogy a településről valaha is el tudnának költözni. Nem tudják az ingatlanjukat értékesíteni, így tulaj- 


\section{TEMATIKUS TANULMÁNYOK - „Hetelők” Kelet-Magyarországon}

donképpen ide vannak kötve. A családtól való távollét okozta nehézségeken úgy próbálnak változtatni, hogy az otthon maradókat is meggyőzik az ingázás előnyeiről. Először a férfi családtagokat, hiszen az építőipar, ahol dolgoznak, főként férfiaknak tud csak nehéz, fizikai munkát adni.

„Eljárunk Szentendrére dolgozni. Az 365 kilométerre van innen. Kéthetente tudunk haza járni. Ott dolgozunk fent, mint segédmunkás, édesapám és az öcsém is. Nagyon szeretném, ha a család is fent legyen velünk, hogy mindnyájan itt dolgozzunk, most azon vagyok, hogy valamilyen lakhatást, szállót keressünk és közösen fent legyünk." (19. interjúalany)

Két nő is volt az interjúalanyaink között, akik a lakóhelyüktől távol dolgoznak. Mindketten szakmai végzettség nélküliek, betanított munkát végeznek. Nehéz, egészségre ártalmas fizikai munkát, ami csak az otthoni bérekhez képest jól fizető.

„Ebben az elektronikai feldolgozó üzemben nemcsak elektronikus dolgok vannak, hanem a vastól, a réztôl kezdve, az alumíniumig minden. Ez egy feldolgozó üzem, igazából darálják a vörös rezet, meg poros, mert minden poros, nagy por van, kalapáccsal dolgozunk, verjük szét a wifis dobozokat. A pesti bérekhez viszonyítva, igazából keveset keresünk, de az itthonihoz képest jó." (21. interjúalany)

Esetükben a helyi szinthez viszonyított magasabb jövedelem sem jelent mobilitási esélyt, legfeljebb ki tudják fizetni korábbi adósságaikat, hátralékaikat. A szakképzetlenségük miatt sem magasabb jövedelemmel járó, sem könnyebb munkára, jobb munkalehetőségre nincs reális esélyük. A nagyvárosi élet ugyanakkor nagyobb kiadással is jár, a hazautazás költségei jelentősek, ezért jellemzően 2-3 hetente vagy annál ritkábban tudnak hazautazni. A család hiányát megpróbálják úgy pótolni, hogy rokonaikat, családtagjaikat meggyőzik a távoli munkavégzés előnyeiről.

Annak ellenére, hogy az interjúalanyaink életkoruk alapján fiatalok, nem gondolkodnak továbbtanulásban. A korábban átélt iskolai kudarcok, az alapkészségek hiánya, de a napi 9-10 órás nehéz fizikai munka kizárja őket a tanulással elérhető mobilitásból. Marad számukra a remény, hogy jó cégekhez kerülnek, ahol kifizetik munkabérüket, nem csapják be és nem diszkriminálják őket származásuk, vidékies gondolkodásuk vagy szakképzetlenségük miatt. 


\section{Összegzés}

A gazdaság fejlődésével, az urbanizációval együtt jár a belső vándorlás, annak mind a két típusa az állandó és az ingavándorlás is. Az emberek lakóhelyet főként családi és foglalkoztatással kapcsolatos indokok alapján változtatnak. Közismert, hogy az ország különböző régióiban eltérő keresetek vannak, ami miatt logikus, hogy a jobban fizető országrészekbe szívesebben mennek dolgozni az emberek. Mivel az ingatlanárak legalább olyan aránytalanok, mint a munkajövedelmek, így a rosszul fizetett országrészekben élőknek esélyük sincs arra, hogy saját tulajdonú házaikat eladva fejlettebb régiókba költözhessenek. Így marad az ingavándorlás. A nagy földrajzi távolságok nehezítik, szinte lehetetlenné teszik a napi ingázást, még akkor is, ha jó a vonatközlekedés vagy autópálya áll rendelkezésre. A heti vagy még ritkább hazautazás a jobb jövedelem mellett sok hátránnyal jár.

Ebben a tanulmányban azt mutatjuk be, hogy az ország gazdaságilag fejletlenebb területein élő interjúalanyaink miért vállalják be az otthontól, családtól való távollétet. A heti ingázást vállalókat legmagasabb iskolai végzettség szerint csoportosítottuk és kerestük azokat a közös jellemzőket, amelyek a diplomás, a középfokú szakmai végzettséggel rendelkezők és az alacsony iskolai végzettségű munkavállalók döntését befolyásolták. A kutatás nem reprezentatív, a mintavétel nem valószínűségi alapon történt. A kapott válaszok meggyőzően bizonyítják, hogy minél alacsonyabb iskolai végzettséggel rendelkező volt az interjúalanyunk, annál inkább jellemző, hogy csökken a választási lehetősége és nem csak a munkahely esetében nem tud válogatni, de még abban is kiszolgáltatott, hogy hol lakjon, mivel töltse, szabadidejét, mikor utazzon haza. A hátrányos helyzetű térségekből érkezők közül a munkahelyek meglehetősen nagy kínálatból választhatják ki a számukra megfelelő munkaerőt, ez a külföldi munkahelyekre legalább annyira érvényes, mint a hazaikra, a fővárosiakra, a dunántúliakra.

A heti ingázást választók jellemzően kényszerhelyzetben vannak, vagy azért, mert lakóhelyükön nincs képzettségüknek megfelelő munkahely, vagy az otthoni lehetőségek csak alacsonyabb presztízsű munkát és jövedelmet nyújtanak vagy, mert helyben egyáltalán nincs munka. A kényszer kisebb nagyobb kompromisszumra kényszeríti a munkát keresőket, el kell fogadniuk a szabad hétvége érdekében a hoszszabb napi munkaidőt vagy az egyszerűbb, komfort nélküli szállást vagy a nagyon ritka hazautazási lehetőséget. Minél alacsonyabb iskolai végzettségű a munkavállaló, annál jelentősebbek ezek a kompromisszumok. Az iskolai végzettség és szakmai tudás nélküliek ezeken a munkahelyeken reprodukálják hátrányos helyzetüket. Az otthoni jövedelmekhez képest magasabb bérek alig jelentenek jobb, kényelmesebb életet, más életmódot. Identitásukban még erőteljesen kötődnek lakóhelyükhöz, a falu világához. Munkahelyükön is a velük hasonlókkal tartanak kapcsolatot, a külföldön dolgozók magyarokkal, a fővárosi, dunántúli munkahelyeken pedig a falubeliekkel beszélgetnek, töltik el szabadidejüket. A hetelők éppen amiatt, mert hétvégeken 


\section{TEMATIKUS TANULMÁNYOK - „Hetelők” Kelet-Magyarországon}

rohannak haza, nem is tudnak, nem is akarnak ilyen jellegú változásnak részeseivé válni.

A nyolcvanas években Losonczi Ágnes a távolsági ingázókat a következőképpen jellemezte.

„A távolsági ingázók a társadalmi átalakulások legnehezebbjét viselik, ha be kell vonni őket az iparba, bevonják, ha ki kell szorítani, kiszorítják őket. Ők részesülnek a legkevésbé a nagy jövedelmekből, a tanulási lehetöségekből, a civilizációs juttatásokból. Számukra csak a kemény munka és a nehéz életkörülmények „járnak”. (Losonczi 1988: 146)

Az interjúk azt bizonyítják, hogy Losonczi Ágnes több mint 30 éves jellemzése ma is helytálló, megkérdezetteink életét jól szemlélteti.

\section{Irodalom}

1960. évi népszámlálás. 9. kötet, KSH, Budapest, 1963.

2011. évi népszámlálás. 8. Foglalkoztatás, munkanélküliség, ingázás. KSH, Budapest, 2014. 28-34. http://www.ksh.hu/docs/hun/xftp/idoszaki/nepsz2011/ nepsz_08_2011.pdf Letöltési idő: 2020.03.31.

Banister, D. (2011): The trilogy of distance, speed and time Journal of Transport Geography 19(4): 950-959.

Bőhm A. - Pál L. (1985): Társadalmunk ingázói - az ingázók társadalma. Kossuth Kiadó, Budapest

Bőhm A. (1997): Ingázás tegnap és ma. MTA Politikai Tudományok Intézete, Budapest

Clark, W. A. V. - Huang, Y. - Withers, S. (2003): Does commuting distance matter? Commuting tolerance and residential change Regional Science and Urban Economics 33(2): 199-221.

Dövényi Z. - Kocsis K. - Tóth J. (2011): Népesedési jellemzők. In: Kocsis K. -Schweitzer F. (szerk.): Magyarország térképekben. Magyar Tudományos Akadémia Földrajztudományi Kutatóintézet, Budapest, 88-99.

Gmelch, G. (1996): Migration and Adaption to City Life. In: Gmelch, G. - Zenner, W. P. (ed.): Urban Life. Reading in Urban Anthropology. Illinois, Waveland

Gordon, P - Kumar, A. - Richardson, H. W. (1989): The influence of metropolitan spatial structure on commuting time Journal of Urban Economics 26(2): 138-151.

Dr. Kovács Z. - Dr. Egedy T. - Szabó B. (2015): Az ingázás területi jellemzőinek változása Magyarországon a rendszerváltás után. Területi Statisztika. 55(3): 233-253. 


\section{TEMATIKUS TANULMÁNYOK - „Hetelők” Kelet-Magyarországon}

Lakatos M. - Váradi R. (2009): A foglalkoztatottak napi ingázásának jelentősége a migrációs folyamatokban. Statisztikai Szemle 87(7-8): 763-794.

Lakatos M. (2013): A foglalkoztatottak időfelhasználása az ingázás és a munkába járás idejének tükrében. KSH, Budapest

Losonczi Á. (1988): A vendégmunkás. In: Korniss P. - Losonczi Á. (szerk.): A vendégmunkás. Mezőgazdasági Kiadó, Budapest

Losonczi K. (1968): Az ingázás iránya, költsége és az ingázók utazási ideje. Statisztikai Szemle 46(7): 731-746.

Tóth E. Zs. (2008): A fekete vonat. Cséplő Gyuri. A pártfogolt - Ingázók a dokumentumfilmekben. Eszmélet folyóirat. 2008. április 1. www.eszmelet.hu Letöltési idő: 2020. 03. 12.

Valuch T. (2001): Magyarország társadalomtörténete a XX. század második felében. Budapest, Osiris 